\title{
Unveiling the Role of Identity in Teacher Education
}

Haldun Kaya*

\section{Summary}

Understanding who teachers are has turned out to be a prerequisite in order to understand language teaching and learning since teaching is not limited to the skills and knowledge of language teaching but it overall covers who a language teacher is. To this effect, teacher identity has emerged as the focus for many researchers. Different learning theories define the nature of teacher identity in their particular terms. In behaviourism, the teacher is the information transmitter; in humanism, he is the counsellor. In constructivist theory, the teacher is the designer of educational experiences. Like behaviourism and humanism, constructivism focuses only on the psychological and mental dimensions and neglects the social role of teaching, teachers' relations with each other, and the expectations of others. As teacher identity is a social phenomenon that can be constructed, reconstructed or developed in a social environment, this directs us to socio-constructivist theory. The teacher acts like a designer and mediator of educational and social experiences and creates a democratic learning environment which is appropriate for peer interaction and collaborative learning. Why some teachers can develop their identity and how they can do that is another intriguing aspect. What happens in the shifting from one identity to another? Who or what influences the change? How should teacher education programmes approach teacher identity development/ reconstruction? This article also focuses on the roles of teacher educators and the professional development activities conducted to help teachers develop their teacher identity.

Key words: Teacher Identity, Teacher Education, Socio-Constructivism, Re-Construction.
$\ddot{\boldsymbol{O} z}$

\section{Öğretmen Eğitiminde Kimlik Rolünü Açığa Çıkarmak}

Öğretmenlerin kim olduğunu anlamak dil öğrenimi ve ögretimini anlamanın bir önşartıdır çünkü ögretmenlik dil ögretimi bilgi ve becerileri ile sınırl olmayıp genl itibariyle bir dil ögretmeninin kim olduğunu kapsamaktadır. Bu doğrultuda, ögretmen kimliği pek çok araştırmacının ilgi alanı haline gelmiştir. Farklı öğrenme kuramları ögrretmen kimliğinindoğasını kendineözgü ifadelerle tanımlar. Davranışçı yaklaşımda öğretmen bil aktaran; Insancılik'ta ise danışmandır. Yapılandırmacilik kuraminda öğretmen eğitimsel faaliyetlerin tasarımcısıdır. Davranışçılık ve İnsancilık'ta olduğu gibi, Yapılandırmacı yaklaşımında da psikolojik ve zihinsel boyutların üzerinde durulmuş öğretimin sosyal rolü, ögretmenin ilişkileri ve ögretmenin diğer kişilerden beklentileri göz ardı edilmiştir. Bu durum bizi sosyal yapılandirmacı kuramina yönlendirir çünkü ögretmen kimliği sosyal bir ortamda yapilandirilan, yeniden yapilandirilan ya da geliştirilen bir olgudur. Sosyal yapilandırmacılikta ögretmen, eğitim ve sosyal faaliyetlerin tasarımcısı olarak hareket eder ve işbirlikli öğrenme ve ögrencilerin birbirleriyle etkileşimi için uygun ögrenme ortamı yaratır. Neden bazı ögretmenlerin kimliklerini geliştirebildiği ve bunu nasıl yaptıkları dikkat çeken bir başka konudur. Bu değişim strasında neler olur? Bu değişime kim ve ne etken olur? Öğretmen eğitim programlarının ögretmen kimliği geliştirme / yeniden yapılandırmaya yaklaşımı nasıl olmalıdır? Bu makale ögrretmen eğitimcilerinin rolleri ve öğretmen kimliğini geliştirmek amaçl mesleki gelişim faaliyetleri üzerinde de durmaktadır.

Anahtar kelimeler: Öğretmen Kimliği, Öğretmen Eğitimi, Sosyal-Yapılandırmacılık, Yeniden Yapilandirma.

* 


\section{Introduction}

For many years, teachers were regarded simply as the practitioners of certain approaches and educational theories. However, the nature of the teaching and learning environment has proved that reality is much more complex due to many variables. Especially, the teacher plays a key role in the classroom practices; hence, the role of the teacher has become the focus for many researchers. Varghese, Morgan, Johnston and Johnson (2005, p. 22) state that "initial explorations of teacher beliefs, knowledge, attitudes, and so on also made it clear that such attributes could not be seen atomistically but that it was the teacher's whole identity that was at play in the classroom". Naturally, teacher identity is considered as an inseparable component of teacher education, because what teachers do both inside and outside the classroom, is the reflection of how they perceive themselves. Recent literature in teacher education emphasizes the importance of identity development; however, it remains unclear how teacher identity development is addressed in teacher education and training programmes (Beauchamp and Thomas, 2009). Thus, there is a need to evaluate teacher identity development, especially from social and cultural perspectives.

Although "linguistic assimilation and thus membership in the imagined community of native speakers, is not necessarily a desired outcome" (Pavlenko, 2003, p. 251), in many parts of the world, for many years, language teachers whose mother tongue is not English have been at a disadvantage. The reason for this could be claimed that a teacher identity has been limited to simply copying a native speaker. The negative repercussions could be stated as a general low self-esteem, lack of confidence and demotivation. Cook (1999) points out adult learners' attempts to attain native-speaker standards are a 'failed enterprise', because that goal is physically impossible. If non-natives fail to speak the way a native does, "it is like saying ducks fail to become swans" (Cook, 1999, p. 187) There are also other traits that cannot be changed such as their race or colour, which can give rise to the feeling of second-class citizenship. "In seeking to address inequities, critical teacher educators encourage teacher learners to critically reflect on their own identities and positioning in society" (Hawkings and Norton, 2009, p. 5). As Pavlenko (2003, p. 251) argues, teacher educators could help teachers regard themselves as "multicompetent speakers and legitimate L2 users rather than failed native speakers of the target language". With their restored and re-shaped identities, they can feel more confident and ready to take up innovative roles and actions not only in teaching, but in their general professional development as well.

\section{Teacher Identity as a Root of Learning Tehories}

A teacher's identity is shaped and reshaped in interaction with others in a professional context (Beauchamp and Thomas, 2009). However, behaviourist-oriented theories assign cer- 
tain roles to teachers such as the information transmitter. In fact, the nature of teacher identity described in any particular teaching and learning approach mirrors the tenets of that approach. In this section, the main learning theories are reviewed in order to understand the inter-relation between a teacher and other main components in the process of learning, including learners, educational materials and classroom environment including the seating plan and interaction patterns.

1.1. Behaviourism is a theory of animal and human learning that focuses only on objectively observable behaviours, and discounts mental activities. "The learning of any skill is seen as the formation of habits, that is, the creation of stimulus-response pairings which become stronger with reinforcement" (Mitchell et al. 2013, p. 28). The teacher, who is the information transmitter and the main role player in the process of learning, regards the students as empty slates (i.e. tabula rasa), and their behaviour is shaped through the teacher's positive and negative reinforcement.

For teacher education, behaviourism offers model-based learning which includes classical micro-teaching, competency-based teacher education and craft approach. In micro teaching, pre-service or in-service teachers are asked to imitate sample models of target behaviours. Competency-based teacher education is an objectives-driven approach which provides the teachers with aims which are stated as observable behaviours. In the craft model, a student-teacher shadows an experienced master teacher and learns how to teach. In these three types of model-based learning, the starting point is that pre-service or in-service teachers are regarded as passive recipients; and the teacher educators are the ultimate role models, providing models of action and behaviour.

The aim in model-based teacher education is not to influence mental skills or cognition, but only to shape or change behaviour. This brings about the inherent transfer problems as each context is different, it is impossible for the student teachers to replicate what they have observed. Model-based training may give student teachers temporary self-confidence, but they will realize that the techniques do not work in every context, so "he is left naked in the classroom" (Roberts, 2016, p. 17), as contextual variety and cognitive traits are ignored. There is no one-size-fits-all model at all. Another problem is that the models taken as target behaviours and the craft knowledge of the master teacher could be dated and inappropriate for the current teaching settings. In addition, the emphasis on imitation denies the freedom of self-planning or self-evaluation. Clearly, a teacher education programme solely based on behaviourism is unlikely to succeed. 
As a teacher trainer, I have noticed that most training activities correspond with the tenets of behaviourism. The aim of many workshops is to demonstrate exactly how to conduct activities. Similarly, the purpose of classroom observations is to identify strengths and weaknesses. In the feedback sessions, what to do and what not to do is directly prescribed. As an approved tutor of an internationally recognized teacher training course, I have also realized that most of the training is behaviourist-inspired:

- the imposed input sessions (The title itself is self-evident: input session)

- the prescriptive guidelines given by the tutor in lesson planning sessions

- the observations to identify strengths and weaknesses

- the feedback sessions to reinforce the desired behaviour

The underlying reason why many PD activities are conducted in the way described above is the identity that teacher educators have.

1.2. Humanism: In humanism, the identity given to the teacher is that of a counsellor. Teacher should give priority to learners' freedom and potential. Humanistic psychology is against the behaviourist notion that all behaviour is reactive and shaped by the teacher and external factors. "Human learning theory is concerned with personal growth and includes attention to students' affective dimensions such self-concept, values and emotions" (Johnson, 2014, p. 2). Everyone has self-agency (Roberts, 2016) to realize self-actualisation (Dodd, 2001) and self-directed development (Beatty, 2000) in a positive environment.

A humanistically-inclined teacher educator is expected to give importance to fostering a democratic environment in which student-teachers' autonomy is respected, and in which they feel a degree of equality with their mentors. To this effect, "teacher educators need to help teachers relate to their practice from a position of strengths rather than weak areas" (Norton, 2005, p. 16). Teachers need freedom in order to self-determine their development, rather than relying on imposed models. Although humanistic theory allows for individualism and critical learning, there are certain fundamental drawbacks that cannot be ignored. First of all, inner sources alone may not be adequate for self-realization. Many teachers do not know what they know, so it is improbable to detect the points to be worked on without the guidance of a mediator. Secondly, in humanism, the social perspective is totally neglected, since learning is regarded as purely an individual experience. If teachers want to develop themselves and become better equipped and more professional, they cannot ignore either the demands of their social 
context or their interactions with others in their social and occupational settings. The defects of humanism gave rise to the emergence of new learning theories, including constructivism.

1.3. Constructivism is a descriptive rather than a prescriptive theory of learning (Richardson, 1997). It is stressed that a learner's mind gets input from the world to produce its own reality. Piaget claims "mental representation or construction is the means by which we internalise knowledge and perceive the world" (Johnson, 2016, p. 23). "Rather than viewing knowledge as truth, constructivists construe it as a working hypothesis" (Schunk, 2012, p. 230). This idea is supported by Dewey (1938, p. 64), who argues that "there is no intellectual growth without some reconstruction, some reworking". Thus, the internal representation of knowledge is constantly open to change. For the construction and change in the mental representations in a learner's mind, the teacher acts like a designer of educational experiences.

Cognitive theory emphasizes that instruction must be based on a student's existing mental structures, - schema-, to be effective. Constructivism regards learning as an individual cognitive experience, and consequently, introduces a number of techniques for self-study. Constructivist education often invokes to the following learning activities:
a. Mnemonics
b. Chunking
c. Analogies
d. Metaphors
e. Concept mapping
f. Schema theory

Constructivist teacher educators claim that internalization and deep understanding cannot be realized via transmission or imitation. Models are used to enrich student-teachers' repertoire of teaching, rather than dictating prescribed techniques. The analysis of these models in the feedback sessions also helps the teachers' conceptual development as well as providing skills training. Since individual differences are of paramount importance in constructivism, teacher educators feel the need to start any training from each teacher's particular point of development. Kolb's theory of experiential learning is also useful in teacher education. He regards the cycle of personal ex 
perience in the classroom, reflection on what has happened on site, abstract conceptualisation of new perceptions and active experimentation of these new ideas as "freeing the person from unthinking reliance on received knowledge" (Johnson, 2016, p. 35). However, like the theories mentioned in this section, constructivism focuses on the individual, and neglects the social role of teaching, teachers' relations with others, and the expectations of others. Varghese et al (2005, p. 39) state that "the formation, negotiation, and growth of teacher identity is a fundamentally social process taking place in institutional settings such as teacher education programs and schools". As teacher identity is a social phenomenon, not limited to individual, mental or observable behaviour changes, this directs us to socio-constructivist theory.

1.4. Socio-constructivism argues that as humans are social beings, whatever we experience is social. Learning can neither be regarded as a solely personal cognitive process, nor be separated from its social context. All cognitive activities are, in fact, the products of social interactions. According to Vygotsky (1978, p. 57), "every function in the child's cultural development appears twice: first, on the social level and, later on, on the individual level; first, between people (interpsychological) and then inside the child (intrapsychological)".

\section{The following depicts the sociocultural perspective on learning:}

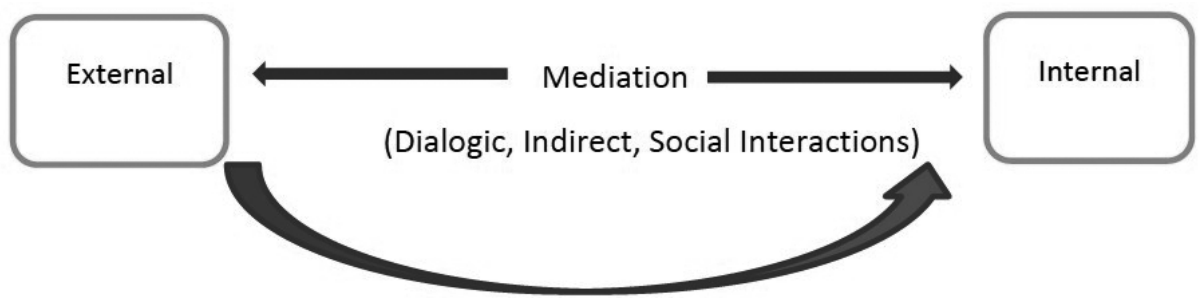

The teacher acts like a designer and mediator of educational and social experiences and creates a democratic learning environment appropriate for peer interaction and collaborative learning. The teacher needs to help the students feel safe enough to question and reflect on their own processes. A socio-constructivist teacher can act as follow:

- Creating a democratic environment with the help of interpersonal skills, creating good rapport with students, and changing the seating plan (e.g. by creating a U shape seating plan).

- Encouraging students to have a critical mind towards what they have learnt, and what they have been doing. 
- Asking students to use higher order thinking skills (assignments should not be just a summary of what they have understood, but a synthesis)

- Helping students realize that each one of them is a source of information. What the students have brought to his class is valuable for everyone.

- Social interactions taking place in the classroom are the key to learning. In this process, the teacher has the role of a mediator.

The importance of interpersonal skills and the mediator role of the teacher in social interactions emphasize that teaching cannot be reduced to theoretical knowledge, or a set of skills. It is a "process of socialization" (Johnson, 2016, p. 36). Neither can teaching be separated from its context.

\section{Implications of Sociocultural Theory for Teacher Education}

Johnson and Golombek (2016, p. 3) claim that discovery learning alone should not be used as the method of learning to teach since learning is "intentional, deliberate and goal-directed" in a social setting; without a social environment, there is no learning. The teacher educators are not the source of information, but the guide of the mediatees through social interactions, such as mutual discussions.

Narrative activity (Johnson and Golombek, 2016) has the three functions that are of paramount importance stated below:

\section{Table 1: The Functions of Narrative Activity}

\begin{tabular}{|l|l|}
\hline Externalization & $\begin{array}{l}\text { - Opening up the mind. Helping teachers see } \\
\text { the link between their tacit knowledge and } \\
\text { practice. } \\
\text { Expressing understandings and feelings about } \\
\text { the past, present and future experiences. }\end{array}$ \\
\hline Verbalization & $\begin{array}{l}\text { - Connecting theory to practice. } \\
\text { - Using academic concepts to analyse everyday } \\
\text { concepts. }\end{array}$ \\
\hline Examination & $\begin{array}{l}\text { - Noticing the underlying reasons for the con- } \\
\text { cepts and activities. }\end{array}$ \\
\hline
\end{tabular}




\section{Identity as a Mediator}

In socio-constructivist theory, a teacher is regarded as a mediator of educational and social experiences. The role of a mediator is directly linked to teacher identity, as the teacher is not seen as an information transmitter (as in behaviourism), a counsellor (as in humanism) or a designer of educational experiences (as in constructivism). The new and more comprehensive identity reshapes the ways that learning and teaching take place. Why is mediation so important? Because it is the key to higher order thinking processes and learning. A mediator uses physical tools (e.g. language) and psychological tools (e.g. interactive activities) to make changes in students' thinking (Johnson and Golombek, 2016). However, attaining the identity of a mediator may be a long process. Teachers and teacher educators first need to have internalized the concepts or skills that they aim to teach and also be aware of the procedures/stages of internalization. They also need to develop ways of externalization.

As a mediator, a socio-constructivist teacher employs scaffolding. Scaffolding could appear easy in theory, but not in practice, because of its ill-defined nature regarding when, how much and how to help. Too much scaffolding decreases learner agency; on the other hand, lack of assistance results in frustration (Johnson and Golombek, 2016). Dialogic social interactions between teachers and educators in joint activities constitute the mediation, through which scaffolding is determined. Teachers and teacher educators may have different purposes in such a joint activity; one of the tasks of the mediator is to generate curiosity and desire for new motives. Teacher educators may tap the learning potentials of the teachers with thought provoking questions which will guide them to a new learning experience in the future which is beyond their current potential. This paves way for the teacher educators to engage in more scaffolding. For example, I carried out a teacher research project with one of the teachers in my current institution, about the effects of online discussions on the students' speaking ability. The results were so intriguing that the teacher was inspired to do another research on the students' speaking ability and the effective use of a learning management system users and groups. This highlights that previous learning experience can open the door to the new experiences.

Perezhivanie, i.e. the subjective interpretations of teachers' own experiences, is also important for teachers, as such interpretations are an integral part of sociocultural dialectic interactions. However, perezhivanie has been neglected in many teacher education programmes and courses. Interthinking (Mercer, 2000), i.e. thinking together, allows teacher educators and teachers to share mental resources and to achieve more together.

The key points of the learning theories and their links to teacher identity explained above can be displayed in Table 2 : 
Table 2: Learning theories and teacher identity

\begin{tabular}{|c|c|c|c|c|}
\hline & Behaviourism & Humanism & Constructivism & $\begin{array}{c}\text { Socio- } \\
\text { Constructivism }\end{array}$ \\
\hline Teacher as & $\begin{array}{l}\text { An information- } \\
\text { transmitter }\end{array}$ & A counsellor & $\begin{array}{l}\text { A designer of } \\
\text { educational } \\
\text { experiences }\end{array}$ & $\begin{array}{l}\text { A designer and mediator } \\
\text { of educational and social } \\
\text { experiences }\end{array}$ \\
\hline Learner as & A sponge & A self-agent & A constructor & A social constructor \\
\hline Learning as & $\begin{array}{l}\text { An individual } \\
\text { experience }\end{array}$ & $\begin{array}{l}\text { An individual } \\
\text { experience }\end{array}$ & $\begin{array}{l}\text { An individual } \\
\text { experience }\end{array}$ & $\begin{array}{l}\text { Both an individual } \\
\text { and a social experience }\end{array}$ \\
\hline $\begin{array}{l}\text { Teacher } \\
\text { Education }\end{array}$ & $\begin{array}{l}\text { Imitate the models } \\
\text { given }\end{array}$ & $\begin{array}{l}\text { Use the inner } \\
\text { sources for } \\
\text { self- } \\
\text { realization }\end{array}$ & $\begin{array}{l}\text { Analysis and reflec- } \\
\text { tion of the models and } \\
\text { teaching experience } \\
\text { Experiential learning }\end{array}$ & $\begin{array}{l}\text { Collaborative activities } \\
\text { Team teaching } \\
\text { Narrative activity } \\
\text { Action research } \\
\text { Interthinking }\end{array}$ \\
\hline
\end{tabular}

\section{Conclusion}

One of the intriguing aspects of teacher identity is how it shifts and is reshaped. What occurs during in the shifting from one identity to another? Who or what influences the change? How should teacher education programmes approach teacher identity development/ reconstruction? It is not easy to answer these questions. However, it is clear that if a teacher acts like a passive recipient and does nothing more than immersing himself in imposed training sessions, the results are unlikely to be satisfactory. Vygotsky (1986, p. 150 ) also stated that "direct teaching of concepts is impossible and fruitless". Thus, teacher educators could also encourage teachers to participate in teacher research, action research, reflective practice, interthinking, team teaching and other professional development activities involving collaboration. The common feature of these activities is that teachers take the role of independent learners and self-direct their learning so that they can choose to work on the areas of interest, or on the points in need of improvement. When learning from each other or taking new roles and duties (e.g. researcher, mentee, team member, observer), teachers reshape the concept of identity in their mind. Identity is not a fixed phenomenon, but changes with social and cultural interactions with individuals in the professional and social settings. Teachers could notice the influence of the society on themselves and also their own influence on the others. To this effect, teacher educators need to set 'equity' in terms of the roles that they take as teachers and teacher educators. Teachers need to be able 
to negotiate democratically and critically, and to make changes without the hindrance of feeling inferior or intimidated.

\section{References}

Beatty, B. R. (2000). Teachers leading their own professional growth: self-directed reflection and collaboration and changes in perception of self and work in secondary school teachers. Journal of In-Service Education. 26:1, 73-97.

Beauchamp, C. Thomas, L. (2009). Understanding Teacher Identity: An Overview of Issues in the Literature and Implications for Teacher Education. Cambridge Journal of Education. 39:2, 175 $-189$.

Cook, V. (1999). Going beyond the native speaker in language teaching. TESOL Quarterly, 33, 185-209.

Dewey, J. 1938. Art as Experience. New York: Minton, Balch.

Dodd, A. W. (2001). From survival to self-actualization: reflections on teaching and teacher education. The High School Journal. 84:3, 13-18.

Hawkings, M. and Norton, (2009). B. Critical Language Teacher Education. In A. Burns \& J.

Richards, Cambridge Guide to Second Language Teacher Education. (pp. 30-39), Cambridge: Cambridge University Press.

Johnson A. (2014). Educational Psychology: Theories of Learning and Human Development, EL Cajon, CA: National Science Press.

Johnson and Golombek (2016). Mindful L2 Teacher Education. New York: Routledge, 3-46.

Mitchell R., Myles F. and Marsden E. (2013). Second Language Learning Theories,

New York: Routledge, Third Edition.

Mercer, N. (2000). Words \& Minds: How we use language to think together. London: Routledge.

Norton, B. (2005). Towards a Model of Critical Language Teacher Education, Language Issues, Volume 17 , No 1, 12-17.

Pavlenko, A. (2003). “I never Knew I was a Bilingual”: Reimagining Teacher Identities in TESOL, Journal of Language, Identity and Education, 2(4), 251-268.

Richardson, V. (1997). Constructivist Teacher Education Building a World of New Understandings, London: The Falmer Press.

Roberts, J. (2016). Language Teacher Education, London: Routledge.

Schunk, D. H. (2012). Learning Theories An Educational Perspective (Sixth Edition), Boston: Pearson.

Varghese, M., Morgan, B., Johnston, B., Johnson, K. A. (2005). Theorizing Language Teacher Identity: Three Perspectives and Beyond. Journal of Language, Identity and Education. 4:1, 21 - 44.

Vygotsky, L. S. (1986). Thought and Language (Rev. ed.), Cambridge: MIT Press.

Vygotsky, L.S. (1978). Mind in Society. London: Harvard University Press. 